\title{
Influence of protected areas on fish assemblages and fisheries in a large tropical river
}

\author{
Friedrich Wolfgang Keppeler, Gustavo Hallias \\ and Renato Azevedo Matias Silvano
}

\begin{abstract}
Protected areas are one of the main tools for biological conservation worldwide. Although they have contributed to an increase in fish abundance and alleviated the impacts of fishing on marine ecosystems, the impacts of fishing and of protected areas in freshwater ecosystems are less well known. We compared fishing productivity and fish assemblage descriptors of two distinct protected areas designated for sustainable use of natural resources and an unprotected area in the Tapajós River, in the Brazilian Amazon. Two hypotheses were tested: (1) fishers from protected areas have higher catch per unit effort than those from unprotected areas; and (2) fish assemblages in protected areas have higher biomass, abundance, presence of target species, species richness, fish size and mean trophic level than those in unprotected areas. A total of 2,013 fish landings were recorded and two surveys were undertaken to sample fishes. Eleven environmental parameters were quantified to distinguish between effects of environmental heterogeneity and protected areas. The catch per unit effort of fishers was higher within protected areas than in unprotected areas, suggesting that protected areas reduce the levels of fishing pressure and increase fishing productivity. However, the fish assemblage descriptors were correlated more with environmental variables than with protected areas, indicating a relatively weak effect of protected areas on fish communities in lakes. The results highlight the importance of considering the influence of environmental heterogeneity in fish conservation programmes, and the positive effect of protected areas on fishing productivity in freshwater environments.
\end{abstract}

Keywords Conservation units, environmental impacts, fish conservation, fisheries management, small-scale fisheries, spatial heterogeneity

To view supplementary material for this article, please visit http://dx.doi.org/10.1017/So030605316000247

Friedrich WolfGang Keppeler ${ }^{*}$ (Corresponding author) Department of Wildlife and Fisheries Sciences, Texas A\&M University, PO Box 77843-2358, College Station, TX, USA. E-mail fkeppeler@gmail.com

Gustavo Hallwass $\dagger$ and Renato Azevedo Matias Silvano Department of Ecology, Federal University of Rio Grande do Sul, Porto Alegre, Brazil

*Also at: Department of Ecology, Federal University of Rio Grande do Sul, PO Box 15007-91501-970, Porto Alegre, Brazil

$\dagger$ Also at: State University of Santa Cruz, Ilhéus, Brazil

Received 27 October 2015. Revision requested 6 January 2016.

Accepted 19 February 2016. First published online 15 June 2016.

\section{Introduction}

$\mathrm{O}$ verfishing has adversely affected fish communities worldwide, with large and valuable target species being replaced by smaller, lower-value fishes in the so-called fishing-down process (Welcomme, 1999, 2001; Winemiller, 2005; Castello et al., 2013). In marine environments fishing pressure has caused the mean trophic level to decline through the replacement of large predators by small planktivorous fishes, and decreased the mean size and the age of first maturation of exploited fishes (Pauly et al., 1998; Rochet, 1998). These changes to fish communities driven by high fishing pressure may ultimately alter the structure of food webs and the flux of energy and matter in ecosystems (Andersen \& Pedersen, 2010).

Protected areas have been proposed as an efficient way to manage fisheries while simultaneously preserving biodiversity in marine ecosystems (PDT, 1990; Gell \& Roberts, 2003). The density, biomass, species richness and size of fishes are all expected to increase within protected areas relative to surrounding areas (Halpern, 2003). The reduced fishing pressure inside protected areas also benefits large fishes of upper trophic levels, which are usually targeted by fisheries (Claudet, 2011). Besides being established by the government through a top-down approach, protected areas can be comanaged by local communities, with the aim of maintaining traditional livelihoods and the sustainability of natural resources (Lausche, 2011; Lopes et al., 2011; Campbell et al., 2012; Gupta et al., 2016a). Protected areas managed by local people have been successful in some marine environments, increasing the abundance of commercially exploited invertebrates, with ancillary positive effects on the abundance and diversity of non-exploited reef fishes (Gelcich et al., 2008). Furthermore, increased fish stocks in protected areas can result in increased catches and earnings for local fishers (Lockwood et al., 2006). However, in the case of freshwater ecosystems the impacts of fishing and the effects of protected areas are still poorly known (Nel et al., 2007; Suski \& Cooke, 2007; Gupta et al., 2016a). As most protected areas have been designed to protect terrestrial ecosystems (Rodríguez-Olarte et al., 2011), they may fail to mitigate threats to fisheries (Rodríguez-Olarte et al., 2011; Abraham \& Kelkar, 2012). With such an emphasis on terrestrial protected areas, freshwater fishes have often been disregarded in conservation planning in important biodiversity hotspots, such as in the Brazilian Amazon (Castello et al., 2013) and in India (Gupta et al., 2016a,b). 
The Amazon forest is the most protected biome in Brazil, with nearly 2.2 million $\mathrm{km}^{2}$ (43.9\%) within protected areas, $66 \%$ of which are designated for sustainable use (Veríssimo et al., 2011; ICMBIO, 2015). Nevertheless, intensive fishing in the Amazon Basin has resulted in one fish species becoming threatened, and there is evidence of overexploitation of four other fish species (Castello et al., 2013). In some regions there is evidence of the fishing-down process (Welcomme, 1999, 2001; Castello et al., 2011), in which large commercial fish species have been replaced by smaller species (Garcia et al., 2009; Castello et al., 2013), and the effectiveness of most existing protected areas in protecting fish stocks in the Amazon is still unclear. Amazonian fisheries are considered to be moderately selective and the main fish species exploited vary among major river basins (Hallwass \& Silvano, 2015), which may favour management measures on a broad scale. However, the management of small-scale Amazonian fisheries is challenging because of the spatial and temporal heterogeneity of fishing grounds, the diversity of fish species, the variety of fishing gear, and the social context (Bayley \& Petrere, 1989; Isaac et al., 2008; Hallwass et al., 2011, 2013a). Integrated assessments (fish assemblages and fishing) of the effectiveness of protected areas in protecting fish stocks are therefore necessary to determine if protected areas are an appropriate tool for fisheries conservation in the Amazon and in other freshwater ecosystems (Gupta et al., 2016a,b). To our knowledge, no study has compared both the integrity of fish assemblages and fishing productivity among large protected and unprotected areas in this region of high fish diversity.

Our aim was to compare fishing productivity and descriptors of fish assemblage (Table 1) between two distinct protected areas of sustainable use and an unprotected area in the Tapajós River in the Brazilian Amazon. We analysed descriptors of fish assemblage that have been negatively affected by fisheries: fish biomass, abundance, body size, richness, presence of target species and mean trophic level (Table 1). We used a variety of descriptors to conduct a more comprehensive evaluation of the performance of sustainable-use protected areas, which aim to conserve biodiversity, improve fisheries and maintain ecological integrity. We also investigated the influence of local environmental variation on the fish assemblages, to control for potential confounding effects. We tested two hypotheses: (1) fishers from protected areas have higher fishing productivity (catch per unit effort) than those from unprotected areas, and (2) protected areas have higher biomass, abundance, presence of target species, species richness, fish size and mean trophic level (fish assemblage descriptors) than unprotected areas (Table 1).

\section{Study area}

The study areas are located in the lower section of the Tapajós River (Fig. 1). The river water is clear; i.e.

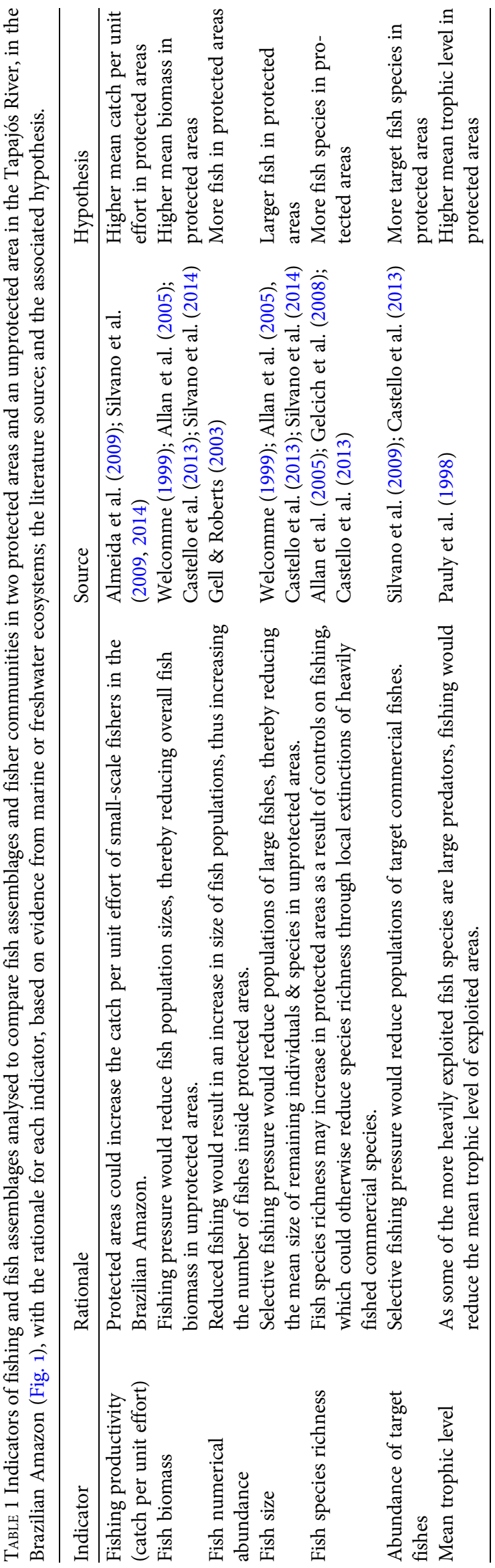




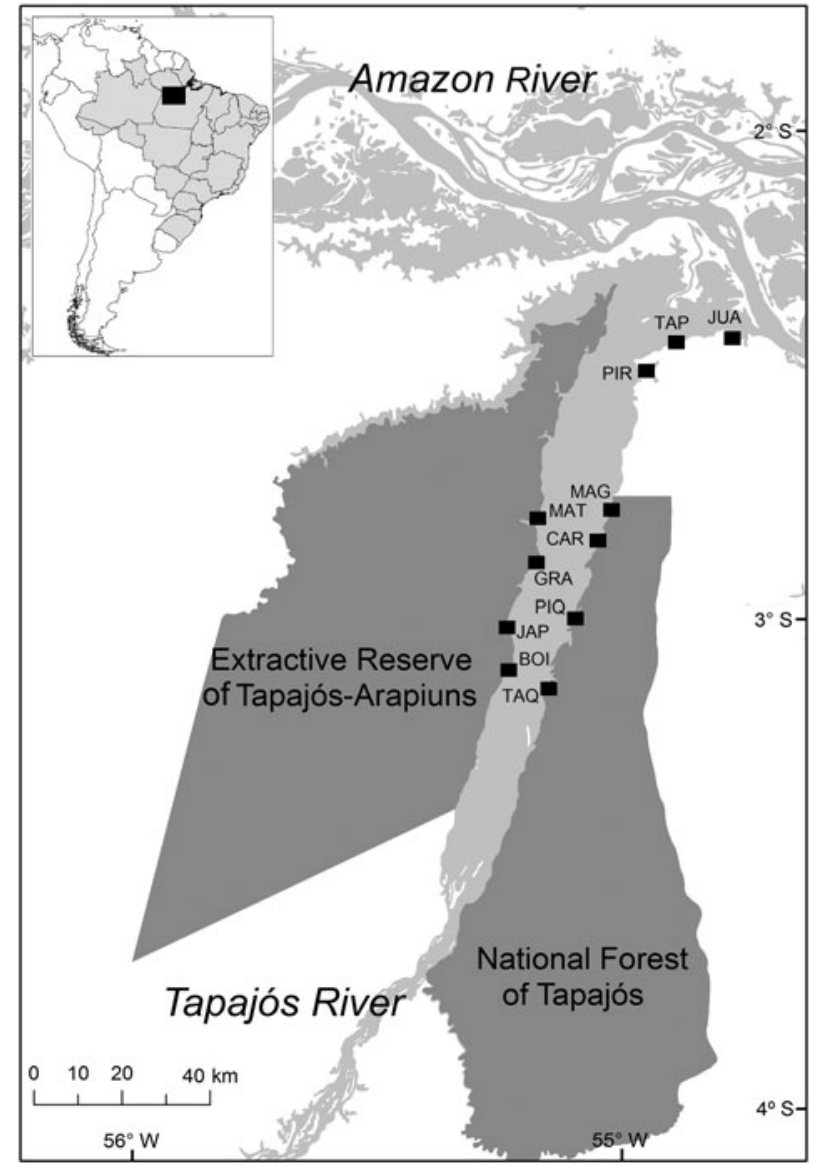

FIG. 1 Location of the 12 floodplain lakes (and associated fisher communities; Table 2) along the Tapajós River, in the Brazilian Amazon, where fish sampling was conducted.

oligotrophic, with low levels of sediment and nutrient concentrations (Goulding et al., 2003). The hydrodynamic characteristics (e.g. flow), water chemistry, and associated terrestrial ecosystems are relatively similar across the studied areas. The climate is tropical humid, with a mean annual temperature of $25.5^{\circ} \mathrm{C}$ and annual variation $<5^{\circ} \mathrm{C}$ (IBAMA, 2004). The mean annual precipitation is 1,820 $\mathrm{mm}$, with high seasonal variation and abundant rains in January-March. Consequently, the water level of the river varies considerably throughout the year $($ c. $5.13 \mathrm{~m})$. The water level peaks in May-June and then declines until November-December, when the lowest water levels occur (ANA, 2012). The floodplain of the lower section of the Tapajós River is a complex landscape of channels, small streams (igarapés), flooded forests, and lakes, which changes from season to season as the water level of the main river changes. Floodplain lakes are connected to the main river during the high-water season and then usually become isolated with the arrival of the low-water season. These lakes are also heterogeneous in terms of size (48.64-1,091.33 $\mathrm{km}^{2}$ ), depth (c. $1.72-5.78 \mathrm{~m}$ ), shape (ranging from round to river-like shapes), water chemistry (e.g. $\mathrm{pH}$, transparency) and habitat structure (e.g. dense macrophyte stands vs a completely open water environment).

There are two protected areas of sustainable use (Fig. 1) in the lower section of the Tapajós River: the National Forest of Tapajós and the Extractive Reserve of Tapajós-Arapiuns. The National Forest was designated in 1974 (IBAMA, 2004), with the primary objective of sustainable use of timber, and since 1992 it has also included faunal protection. The Extractive Reserve was officially designated in 1998, after an almost 20-year struggle by local residents against illegal logging (ICMBIO, 2008). In both protected areas the human population relies on a diversified system of subsistence, including small-scale agriculture, extractive forest production, livestock farming (mainly chickens), fishing and hunting (IBAMA, 2004; ICMBIO, 2008). In relation to fisheries, both protected areas allow only artisanal fishing gear, such as longlines, gillnets, hand lines and harpoons. Larger scale commercial fishing, which generally uses large boats and purse seining to catch pelagic fish species, is prohibited in the main channel of the Tapajós River, between the two protected areas. In contrast, in the surrounding unprotected area the human population density is 10 times higher, and both commercial and artisanal fisheries are common.

\section{Methods}

\section{Sampled lakes and fisher communities}

Four fisher communities were selected in each of the three areas studied (Fig. 1), on the basis that there was a minimum distance of $10 \mathrm{~km}$ between each community and fishers from the community consented to participate in the study. The communities studied are similar to others in the region, which are usually composed of a small number of families (mean $=47.17 \pm S D$ 42.63; Table 2; IBAMA, 2004; ICMBIO, 2008) of mixed origin (indigenous, black and Caucasian), low educational level and low mean wage. After the selection the leader of each fisher community was asked to indicate the floodplain lake most exploited by fishers. These lakes were selected for further analysis of fish assemblages.

\section{Measure of fisheries productivity}

Fish landings of fisher communities were recorded using a participatory method over 12 months, to estimate the catch per unit effort (fish biomass/time spent $\times$ crew size). In an initial stage of the research we interviewed a total of 203 fishers in the 12 communities surveyed. After each interview we invited the fishers who had at least 5 years of elementary education and fished at least three times per week to record their fish landings over a period of 1 year. Fifty-one fishers agreed to participate in this study (Table 2). They were 
TABLE 2 Riverine communities in the National Forest of Tapajós, the Extractive Reserve of Tapajós-Arapiuns and an unprotected area of the Tapajós River (Fig. 1), with the number of families in each community, the number of fishers who participated in the study, the lakes (Fig. 1) in which fish landings were recorded, and the number of fish landings recorded.

\begin{tabular}{|c|c|c|c|c|}
\hline Riverine community & No. of families & $\begin{array}{l}\text { No. of fishers who } \\
\text { participated }\end{array}$ & Lake & $\begin{array}{l}\text { No. of fish landings } \\
\text { recorded }\end{array}$ \\
\hline \multicolumn{5}{|c|}{ National Forest of Tapajós } \\
\hline Maguari & 82 & 3 & Maguari (MAG) & 68 \\
\hline Acaratinga & 20 & 4 & Caranazal (CAR) & 161 \\
\hline Piquiatuba & 86 & 5 & Piquiatuba (PIQ) & 209 \\
\hline Pini & 32 & 8 & Taquara (TAQ) & 367 \\
\hline \multicolumn{5}{|c|}{ Extractive Reserve of Tapajós-Arapiuns } \\
\hline Boim & 92 & 6 & Boim (BOI) & 199 \\
\hline Jauarituba & 52 & 4 & Japequara (JAP) & 173 \\
\hline Surucuá & 95 & 4 & Grande (GRA) & 200 \\
\hline Vila do Amorim & 102 & 5 & Mato (MAT) & 121 \\
\hline \multicolumn{5}{|l|}{ Unprotected area } \\
\hline Pindobal & 37 & 3 & Jurucurí (JUR) & 143 \\
\hline Alter do Chão & $>102$ & 4 & Piranha (PIR) & 189 \\
\hline Ponta de Pedra & 56 & 5 & Taquara (TAQ) & 183 \\
\hline Maracanã & $>102$ & 0 & Juá (JUA) & 0 \\
\hline Total & & 51 & & 2,013 \\
\hline
\end{tabular}

trained individually and each received a pencil, a watch, a scale and forms to record their first five fish landings of each month, starting in August 2013 and finishing in July 2014. For each fish landing, fishers were requested to record the composition and weight of the catch, the fishing site (lake or river), the time spent fishing, and the number of fishers in the crew. Every 15 days, phone calls were made to the fishers, where possible, to discuss and resolve any problems. We collected the fish landing forms at c. 3-month intervals. The fish landing data (fishing gear used, fish species caught) recorded by fishers was positively and significantly correlated with interview data (Hallwass, 2015), indicating the reliability of fisheries data, as shown in a previous study (Hallwass et al., 2013b). More details of this methodology are in Hallwass (2015).

\section{Fish sampling and biological measures}

Two samplings were undertaken in each of the 12 floodplain lakes indicated by the community leaders (Fig. 1; Table 2). The first sampling was in July (high-water season) and the second in November (low-water season) 2013. Fishes were collected using two sets of gillnets (c. $420 \mathrm{~m}^{2}$ each) with different mesh sizes (15-80 mm between opposite knots) during 9.30 \pm SD 0.46 hours (approximately 08.30-18.00). Although our sampling included crepuscular hours, some nocturnal fishes may have been underrepresented (e.g. catfishes). The gillnets were checked every 2 hours and each individual fish captured was measured to standard length $(\mathrm{cm})$, weighed $(\mathrm{g})$, anaesthetized with clove oil, preserved in a $10 \%$ formalin solution and identified to species level. The sampled fishes were also dissected for diet analysis to estimate their trophic position. Ingested prey was identified to the lowest taxonomic level possible (generally family or order). The volumetric method (Herrán, 1998) was used to quantify prey importance. In cases where $<10$ individuals of a species were analysed we gathered additional information on diet from the literature (Supplementary Table S1).

\section{Measurement of environmental characteristics}

Twelve measures of physical-chemical parameters were made at each lake in each season. The $\mathrm{pH}$ and conductivity were measured using a digital water quality tester, the euphotic zone was estimated using a Secchi disk, and the depth was measured using a graduated chord. The percentage of pelagic zone, flooded forest and macrophytes in each lake was estimated visually.

The surface area, shoreline development, and distance to the Amazon River were estimated using images from the Landsat5 satellite (INPE, 2014). The shoreline development was calculated using the following equation:

$$
\text { Shoreline development }=\frac{L}{2 \sqrt{\pi * S}}
$$

where $L$ is the shoreline length and $S$ is the surface area of the lake. In the absence of clear images (without clouds) during the study year, images from the same season but from different years were used (low-water season images from November 2008, and high-water season images from July 2009). The spectral band composition (bands 5, 4, 3 in RGB composition) and image analysis were performed using ArcGis v. 9.2 (ESRI, Redlands, USA). All environmental variables were chosen because of their reported influence 
on fish assemblages in previous studies (Rodriguez \& Lewis, 1997; Tejerina-Garro et al., 1998; Petry et al., 2003).

\section{Fish assemblage descriptors}

The index of relative importance (IRI; Pinkas et al., 1971) was used to determine the importance of each species caught by fishers in the communities studied. It was calculated as follows:

$$
\mathrm{IRI}_{i}=\left(N_{i}+W_{i}\right) \mathrm{FO}_{i}
$$

where $N_{i}$ is the numerical percentage of the $i$ th species in all fish landings, $W_{i}$ is the percentage by weight of the $i$ th species in all fish landings, and $\mathrm{FO}_{i}$ is the frequency of occurrence percentage of the $i$ th species in all fish landings. The index of relative importance was used to calculate an indicator of valuable fish presence (IVFP) in each lake, as follows:

$$
\operatorname{IVFP}_{k}=\Sigma \mathrm{IRI}_{i} \mathrm{RA}_{k i}
$$

where $\mathrm{IRI}_{i}$ is the index of relative importance of the $i$ th fish, and $\mathrm{RA}_{k i}$ is the relative abundance of the $i$ th fish in the $k$ th lake. A high indicator of valuable fish presence in a lake suggests a high proportion of species relevant for fisheries. Thus, we used this index as a surrogate for the presence of target species (Hypothesis 2).

The total biomass and abundance sampled in each lake and in each season (high and low water) was corrected for the sampling effort (time and size of nets). Fish species richness was estimated for each lake and each season by an individual-based rarefaction procedure (Gotelli \& Colwell, 2011). The mean fish size was also estimated for each lake and each season.

The trophic position of each species in the lakes studied was calculated as follows:

$$
T L_{i}=1+\Sigma D C_{i j} T L_{j}
$$

where $\mathrm{DC}_{i j}$ is the fraction of each $j$ th prey in the diet of the $i$ th predator, and $\mathrm{TL}_{j}$ is the trophic level of the $j$ th prey (Pauly et al., 2001). Trophic levels of 1, 2 and 3 were assigned to ingested basal items (detritus, plant, algae), invertebrates and fish, respectively. Although broad, this trophic classification has been used successfully in regions for which little information is available (Hoeinghaus et al., 2009).

The trophic level calculated for each species was used to calculate the mean trophic level (MTL) of each lake and each season, as follows:

$$
M T L_{k}=\sum T L_{i} R A_{k i}
$$

where $\mathrm{TL}_{i}$ is the trophic level of the $i$ th fish and $\mathrm{RA}_{k i}$ is the relative abundance of the $i$ th fish in the $k$ th lake (Pauly et al., 2001). It should be noted that the food webs (and mean trophic levels) of floodplain lakes are not independent of the main river channel (Winemiller \& Jepsen, 1998). In addition, some species present in the lakes may not have been sampled, given the selectivity of our sampling methodology, and some species may exhibit ontogenetic variations in diet. However, the mean trophic level has been considered to be a good surrogate to identify general trends in the disappearance of large predators from unprotected areas (Pauly et al., 1998, 2001). We analysed the diet of fishes of various sizes (for the most abundant species) and during both the low- and high-water seasons (when fishes move between lakes and rivers), and therefore our sampling considered to some extent the influences of connectivity and ontogenetic variations in fish diets. Moreover, the main river channel between the protected areas studied is also under protection from commercial fishing. Thus, we believe that this descriptor could adequately indicate any significant difference in mean trophic level between protected and unprotected areas for the purposes of this study.

\section{Data analysis}

Fishing productivity We grouped fish landings in four main seasons according to the water level: low, rising, high and falling. A linear mixed effects analysis was carried out using the package lme4 (Bates et al., 2014) in $R$ v. 3.2.3 (R Development Core Team, 2014) to test the influence of studied areas (protected and unprotected) on the mean productivity (catch per unit effort) of fishers in each season (Hypothesis 1). Areas, seasons and their interaction term were entered into the model as fixed effects, whereas fishers was entered as a random effect. The statistical significance $(\mathrm{P})$ of each factor was determined by likelihood ratio tests comparing models with and without the variables of interest (Winter, 2013). This mixed model analysis was conducted with two datasets: (1) fish landings from both lakes and the main river, and (2) fish landings from lakes only. This was necessary to understand the effects of fishing on these two environments, facilitating a more accurate comparison with fish sampling, which was conducted only in lakes. The catch per unit effort in both datasets was log-transformed to achieve the normality assumption of the mixed model analysis.

Fish assemblage descriptors Model averaging (Burnham \& Anderson, 2002) was used to obtain robust estimates of relative importance value (I) for the relative effects of environmental variables and studied areas (Hypothesis 2). These two sets of independent variables (environment and areas) were used in linear models as predictors for each of the fish assemblage descriptors (fish biomass, abundance, richness, mean size, mean trophic level and indicator of valuable fish presence) in each season (high and low water). Interaction terms were not included in this analysis, given the limitation of our sampling unit and the high number of predictors. The model averaging analysis generated a relative 
TABLE 3 Results of principal component (PC) analysis (based on the correlation matrix, with percentage of variance accounted for in parentheses) carried out for habitat coverage (macrophytes, flooded forest, pelagic habitat) and physical and chemical (conductivity, $\mathrm{pH}$, depth, euphotic zone) parameters in the low- and high-water periods in the Tapajos River, (Fig. 1). The environmental variables that contributed more for each axis are in bold. The percentage of explanation of each axis is given in parentheses.

\begin{tabular}{|c|c|c|c|c|c|c|}
\hline \multicolumn{3}{|l|}{ Habitat coverage } & \multicolumn{4}{|c|}{ Physical and chemical parameters } \\
\hline \multirow[b]{2}{*}{ Variables } & Low water & High water & \multirow[b]{2}{*}{ Variables } & \multicolumn{2}{|l|}{ Low water } & \multirow{2}{*}{$\frac{\text { High water }}{\text { PC1 }(33 \%)}$} \\
\hline & PC1 $(85 \%)$ & PC1 $(78 \%)$ & & $\mathrm{PC} 1(69 \%)$ & PC2 (48\%) & \\
\hline Macrophytes & -0.65 & -0.03 & Conductivity & -0.39 & -0.51 & -0.44 \\
\hline Flooded forest & -0.10 & 0.72 & $\mathrm{pH}$ & -0.15 & 0.79 & -0.55 \\
\hline \multirow[t]{2}{*}{ Pelagic habitat } & 0.75 & -0.68 & Depth & 0.65 & -0.27 & -0.50 \\
\hline & & & Euphotic zone & -0.62 & -0.15 & 0.50 \\
\hline
\end{tabular}

importance of $0-1$. To avoid multicollinearity between predictors we carried out a principal component analysis based on the correlation matrix, to group the following variables into principal component axes in both seasons: the percentage of pelagic zone, flooded forest and macrophytes (habitat coverage; Table 3), and the conductivity, $\mathrm{pH}$, depth and euphotic zone (physical and chemical parameters; Table 3). The model averaging procedure was conducted in the package glmulti (Calcagno, 2013) in $R$, and the principal component analysis was computed in the package stats $(\mathrm{R}$ Development Core Team, 2014).

\section{Results}

\section{Fishing productivity}

A total of $18,241 \mathrm{~kg}$ of fish was recorded, in 2,013 fish landings (9.07 \pm SD $12.74 \mathrm{~kg}$ per landing). Of these fish landings, $67.2 \%$ were in the main river and $32.8 \%$ in lakes (Supplementary Table S2). The jaraqui (Semaprochilodus spp.; index of relative importance $=6.68$ ) and pescada (Plagioscion spp.; index of relative importance $=6.35$ ) were the main fish caught (Supplementary Table S2). The interaction term between season and areas was significant for the catch per unit effort $\left(\chi^{2}(6)=1,417.7, \mathrm{P}<0.001\right)$ when considering both lakes and the main river environments. The catch per unit effort was higher in fisher communities in the protected areas, as expected (Hypothesis 1; Fig. 2a). The only exception occurred in the low-water season, when the catch per unit effort was similar across all areas (Fig. 2a). However, when considering only fish landings from lakes, the catch per unit effort did not differ among areas $\left(\chi^{2}(6)=0.29, P>0.05\right.$; Fig. $\left.2 b\right)$ and there was no interaction between areas and seasons $\left(\chi^{2}(6)=6.6, \mathrm{P}>0.05\right)$.

\section{Fish assemblage descriptors}

A total of 879 fishes of 67 species were collected (Supplementary Table $S_{3}$ ). The area (National Forest of
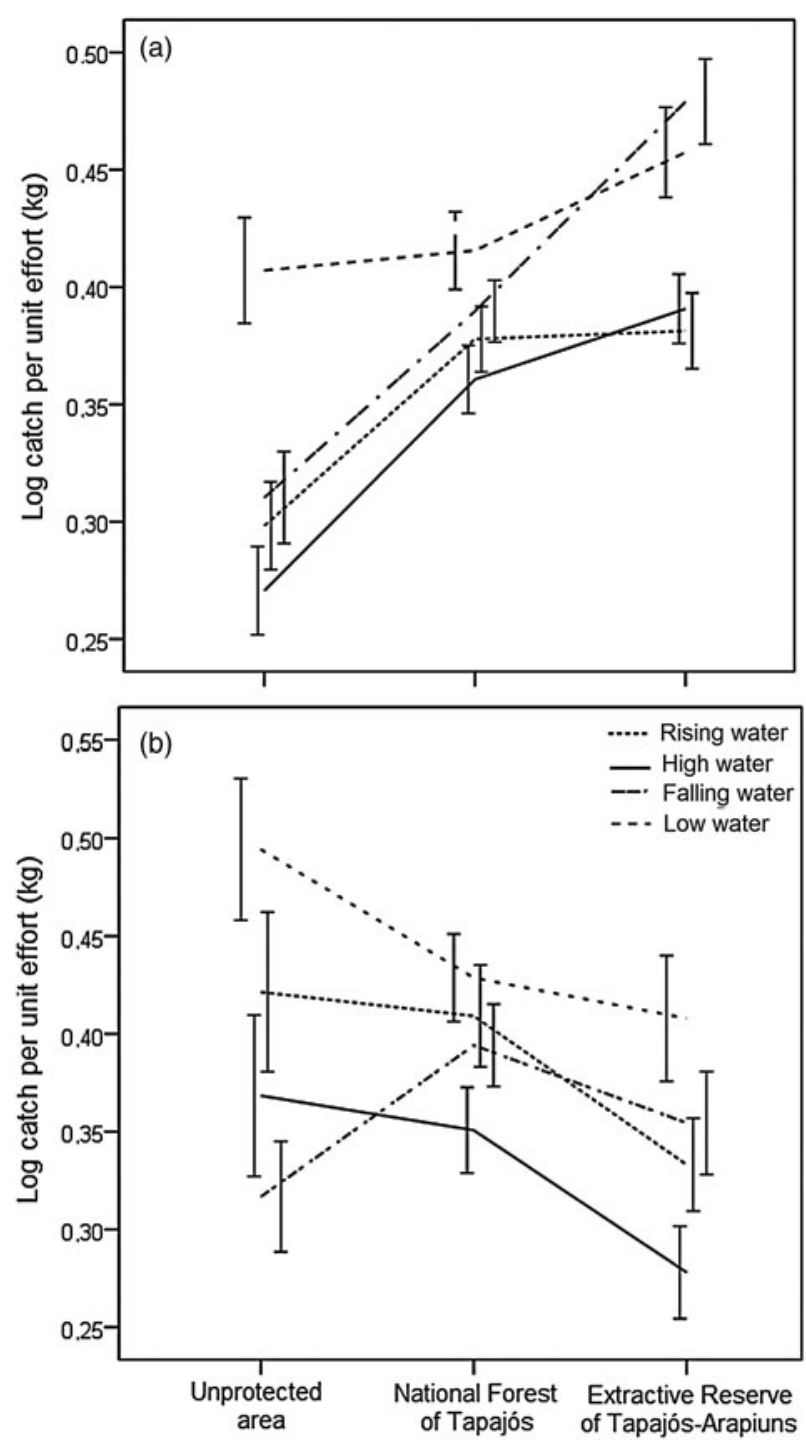

FIG. 2 Catch per unit effort $( \pm \mathrm{SE})$ of fishers in the main river and floodplain lakes (a) and only in the lakes (b) in two protected areas (National Forest of Tapajós, Extractive Reserve of Tapajós-Arapiuns) and an unprotected area of the Tapajos River (Fig. 1) during the four seasons (high water, rising water, low water and falling water). Log-transformations were computed on base 10 . 
TABLE 4 Model-averaged importance of predictors for the dependent variables biomass, abundance, richness, mean size, mean trophic level, and indicator of valuable fish presence for both high- and low-water seasons in the Tapajos River (Fig. 1). The more important terms are in bold; the parameter estimates (slope) for each variable are in parentheses.

\begin{tabular}{|c|c|c|c|c|c|c|}
\hline Variable & Biomass & Abundance & Richness & Mean size & $\begin{array}{l}\text { Mean trophic } \\
\text { level }\end{array}$ & $\begin{array}{l}\text { Indicator of } \\
\text { valuable fish } \\
\text { presence }\end{array}$ \\
\hline \multicolumn{7}{|l|}{ High-water season } \\
\hline Surface area of lake & $0.09(0.00)$ & $0.07(-0.00)$ & $0.13(0.00)$ & $0.04(0.00)$ & $0.07(0.00)$ & $0.13(0.00)$ \\
\hline Distance from Amazon River & $0.13(-0.00)$ & $0.10(-0.00)$ & $0.17(0.00)$ & $0.04(0.00)$ & $0.07(0.00)$ & $0.11(-0.00)$ \\
\hline Shoreline development & $0.20(-0.01)$ & $0.75(-0.42)$ & $0.33(0.03)$ & $0.86(0.25)$ & $0.12(-0.00)$ & $0.11(0.01)$ \\
\hline Studied areas & $0.28(-0.05)$ & $0.09(-0.06)$ & $0.11(0.01)$ & $1.00(-2.13)$ & $0.13(-0.01)$ & $0.11(-0.01)$ \\
\hline Physical-chemical (PCA1) & $0.31(0.03)$ & $0.09(0.03)$ & $0.16(-0.02)$ & $0.19(0.05)$ & $0.99(-0.09)$ & $0.12(0.01)$ \\
\hline Habitat coverage (PCA1) & $0.42(-0.30)$ & $0.65(-4.21)$ & $0.14(0.09)$ & $0.23(-0.46)$ & $0.23(-0.00)$ & $0.40(-0.73)$ \\
\hline \multicolumn{7}{|l|}{ Low-water season } \\
\hline Surface area of lake & $0.06(0.00)$ & $0.08(0.00)$ & $0.87(0.04)$ & $0.11(-0.00)$ & $0.09(0.00)$ & $0.14(-0.00)$ \\
\hline Distance from Amazon River & $0.07(0.00)$ & $0.08(0.00)$ & $0.08(-0.00)$ & $0.11(0.00)$ & $0.35(0.00)$ & $0.11(-0.00)$ \\
\hline Shoreline development & $0.09(-0.00)$ & $0.07(0.00)$ & $0.10(-0.00)$ & $0.21(-0.03)$ & $0.09(0.05)$ & $0.07(-0.00)$ \\
\hline Studied areas & $0.13(0.00)$ & $0.20(0.26)$ & $0.16(0.08)$ & $0.10(-0.00)$ & $0.88(0.24)$ & $0.90(-0.95)$ \\
\hline Physical-chemical (PCA1) & $0.82(-0.08)$ & $0.87(-1.49)$ & $0.11(-0.02)$ & $0.11(0.01)$ & $0.13(0.00)$ & $0.17(0.04)$ \\
\hline Physical-chemical (PCA2) & $0.07(-0.00)$ & $0.08(-0.03)$ & $0.53(0.33)$ & $0.12(-0.01)$ & $0.07(-0.00)$ & $0.07(-0.00)$ \\
\hline Habitat coverage (PCA1) & $0.74(-0.47)$ & $0.09(-0.17)$ & $0.39(1.17)$ & $0.10(0.01)$ & $0.11(0.00)$ & $0.10(-0.14)$ \\
\hline
\end{tabular}

Tapajós, Extractive Reserve of Tapajós-Arapiuns, or unprotected) was one of the most important variables that influenced the three fish assemblage descriptors: mean fish size in the high-water season $(I=1)$, mean trophic level $(I=0.88)$ and indicator of valuable fish presence $(I=0.9)$ in the lowwater season (Table 4; Fig. 3). However, fish size (Fig. 3d), mean trophic level (Fig. 3e) and indicator of valuable fish size (Fig. 3 f) were not consistently higher inside protected areas, which indicates that Hypothesis 2 is not true.

Environmental variables were good predictors of five of the descriptors studied (biomass, abundance, fish size, mean trophic level and species richness; Table 4). The surface area of the lake was slightly correlated with the richness of fish in the low-water season $(I=0.87$, slope $=0.04)$. Shoreline development was positively correlated with the mean fish size $(I=0.86$, slope $=0.25)$ and abundance $(I=0.75$, slope $=-0.42)$ in the high-water season. The principal component (PCA1) with values of physical-chemical parameters was an important predictor in the high-water season, being negatively correlated with the mean trophic level $(I=0.99$, slope $=-0.09)$. In the lowwater season the first axis of physical-chemical parameters was an important predictor of the decrease in fish biomass $(I=0.82$, slope $=-0.08)$ and abundance $(I=0.87$, slope $=-1.49)$, and the second axis was important in explaining the increase in species richness $(I=0.53$, slope $=0.33)$. The principal component (PCA1) of habitat coverage was strongly correlated with a decrease in fish biomass $(I=0.74$, slope $=-0.47)$ in the low-water season and a decrease in abundance $(I=0.65$, slope $=-4.21)$ in the highwater season. The distance to the Amazon River was not an important predictor of any of the fish assemblage descriptors in either season (Table 4).

\section{Discussion}

Our results show that fishers' catch per unit effort was usually higher in the protected areas, confirming Hypothesis 1. It is unlikely that this result is attributable to the use of different fishing strategies in protected and unprotected areas, as gillnets were the most commonly used fishing gear in all communities studied (Hallwass, 2015). Besides, local fishers on the Tapajós River fish in small paddle canoes or in canoes with underpowered engines, which limits their foraging area to the community surroundings (Hallwass, 2015). Therefore, we conclude that the conditions provided by the protected areas in the Tapajós River, such as lower human population density and some management rules (e.g. a ban on commercial fishing) may act synergistically to reduce the levels of fishing pressure and increase fishing productivity (catch per unit effort) for local fishers. Increased fishing productivity has also been observed at smaller spatial scales, such as in protected areas established in lakes in other regions of the Brazilian Amazon (Almeida et al., 2009; Silvano et al., 2014). The accumulated evidence suggests that involving local people in management decisions for protected areas may be an efficient way to increase fish stocks in large tropical rivers.

Differences in the fishing productivity between the protected and unprotected areas were more pronounced during periods of high water level than periods of low water level. This seasonal difference may be caused by the pulsing dynamic of tropical rivers (Junk et al., 1989). Fishing efficiency is generally higher in the low-water season (Begossi et al., 1999; Maccord et al., 2007), whereas when the water level is high, fishes become more difficult to catch and fishers' catch per unit effort is higher in areas with higher fish 

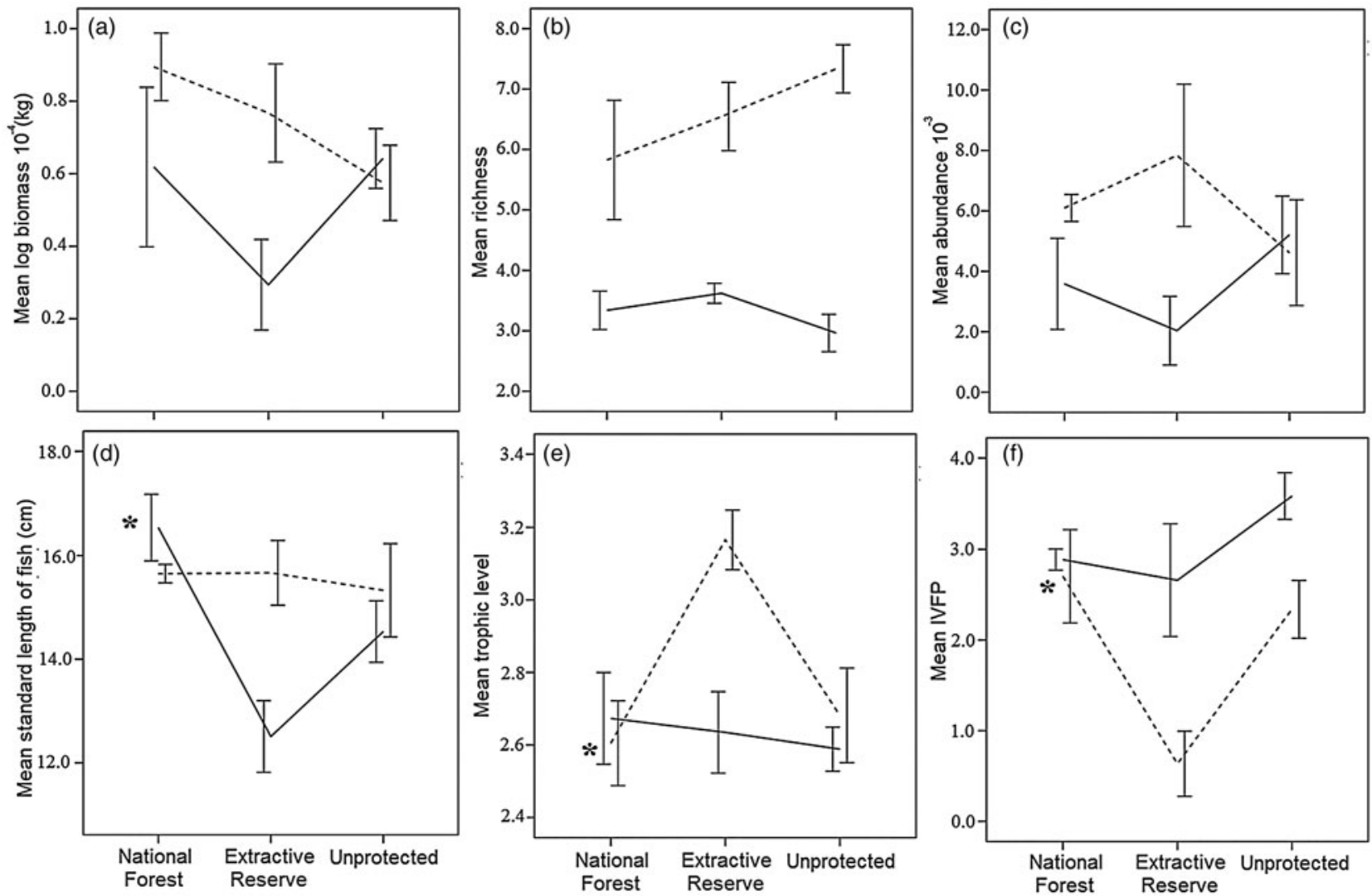

Fig. 3 (a) Mean biomass, (b) mean species richness, (c) mean abundance, (d) mean standard length of fish, (e) mean trophic level and (f) indicator of valuable fish presence (IVFP) of fish catches in floodplain lakes in two protected areas (National Forest of Tapajós, Extractive Reserve of Tapajós-Arapiuns) and an unprotected area of the Tapajos River (Fig. 1) in the high-water (solid lines) and low-water seasons (dashed lines). Asterisks indicate high importance according to the model averaging approach. Error bars indicate \pm SE values. Log-transformations were computed on base 10 .

density, such as protected areas. Another possible explanation is that higher fishing pressure in unprotected areas during the low-water season affects the abundance of fish stocks in the high-water season. In this scenario the recovery of fish stocks in the low-water season could be the result of the interaction between river flow and fish spillover from protected areas, as has been recorded in marine ecosystems (Gell \& Roberts, 2003). Silvano et al. (2009) suggested a similar phenomenon to explain the similarity in terms of fish biomass of non-fished and fished lakes in a co-managed protected area in the Brazilian Amazon (Mamirauá Reserve): non-fished lakes could be a source of fishes for fished lakes in the high-water season, when connectivity between lakes increases. Nevertheless, there is little available information about the spillover effect in freshwater ecosystems (Ounboundisane et al., 2013), and further studies are needed to quantify this effect in freshwater protected areas.

Even with lower levels of fishing and higher fisheries productivity, the National Forest of Tapajós and the Extractive Reserve of Tapajós-Arapiuns alone may be insufficient to conserve and maintain fish stocks in the Tapajós River. The effectiveness of protected areas for fish protection depends on fish movement and the size of the protected area: sedentary animals tend to be better protected than those that cross protected area boundaries (Palumbi, 2004). Most fish species in the Amazon undertake lateral or longitudinal migrations at least once in their life cycle (Barthem \& Goulding, 1997; Fernandes, 1997; Winemiller \& Jepsen, 1998; Galacatos et al., 2004). Some species make seasonal migrations from nutrient-rich waters to oligotrophic waters, such as the Tapajós River, to feed and spawn, increasing the fishing productivity of oligotrophic rivers and consequently the income of fishers (Barthem \& Goulding, 1997; Benedito-Cecilio \& Araujo-Lima, 2002). Fisheries in the Tapajós River exploit species that perform long migrations, such as Brachyplatystoma rousseauxii, Brachyplatystoma filamentosum and Semaprochilodus insignis (Hallwass, 2015), and therefore to guarantee the sustainability of fisheries, and fish conservation in the long term, it may be necessary to create a network of protected areas on a broader scale to ensure connectivity between rivers with nutrient-poor and rich waters.

Although fishers from the two protected areas had a higher catch per unit effort than fishers from the 
unprotected area, we found no effect of protected areas on fish landings originating from floodplain lakes. In experimental fish samples most of the fish assemblage descriptors (e.g. biomass, richness and abundance) did not differ between the two protected areas and the unprotected area. Although there was some variation in mean fish size, mean trophic level and the presence of valuable fishes between the three areas studied, smaller values of these parameters were not consistently observed in the unprotected area; for example, the mean trophic level was higher in the Extractive Reserve but the mean trophic level in the National Forest was similar to that observed in the unprotected area in the low-water season. We therefore conclude that there is no consistent evidence for Hypothesis 2.

The observed low influence of protected areas on fish assemblages and on fishing productivity in floodplain lakes may be a result of the relatively low levels of fishing in this habitat, as most fishes were caught in the main river channel. Besides, local reports suggest that large commercial fishing boats focus mainly on the main river channel of the Tapajós River (Hallwass, 2015). The floodplain of the Tapajós River is smaller, and has fewer lakes, than other rivers of the same order in the Amazon Basin (Goulding et al., 2003), and the mean catch rate $\left(0.54 \mathrm{~g} \mathrm{~m}^{-2} \mathrm{~h}^{-1}\right.$, standardized catch per unit effort) found in floodplain lakes of the Tapajós River was low compared to other Amazonian rivers sampled using comparable methodology (e.g. Solimões, 13.5 g, Silvano et al., 2009; Manacapurú, 14.5 g, Saint-Paul et al., 2000; Lower Tocantins, 2.84 g, Silvano et al., 2014; and Negro, 2.69 g, Silvano et al., 2005). Given the low density of fishes, the floodplain lakes of the Tapajós River may be less attractive for fishers compared to floodplain lakes elsewhere in other Amazonian river basins. Target species, such as Plagioscion spp. and B. filamentosum, were caught almost exclusively in the main river.

The absence of effects of protected areas on fish assemblages in floodplain lakes may also be the result of management on a smaller spatial scale than that addressed by the protected areas. Evidence from qualitative interviews with fishers suggests that of the 12 communities studied, five have some local management initiative in adjacent lakes (Hallwass, 2015). Although we have not assessed the effectiveness of local management here, other studies have shown that local organizations in co-management or commonbased management have been effective in maintaining or even increasing fishing yields and fish abundance in the Brazilian Amazon (Maccord et al., 2007; Almeida et al., 2009; Castello et al., 2009, 2015; Silvano et al., 2009, 2014; Lopes et al., 2011), as well as in other tropical rivers (Gupta et al., 2016a) and marine ecosystems (Campbell et al., 2012).

The biological descriptors of fish assemblages in lakes were more related to environmental variables than to the existence of protected areas. Physical-chemical parameters, lake size and shape, and habitat coverage strongly affected the abundance, size and trophic levels of fishes. These results corroborate findings in other tropical rivers (Rodriguez \& Lewis, 1997; Tejerina-Garro et al., 1998; Petry et al., 2003; Miranda, 2011). Our results also indicate that the response of fish assemblages to environmental conditions varies according to the season. The fish assemblage descriptors measured were correlated with different environmental variables in the low- and high-water seasons, and this may be attributable to several factors, including changes in fish density (Arrington et al., 2005), species composition (Fernandes, 1997), and the range of environmental parameters (Junk et al., 1989). Influential environmental variables should be recognized and addressed in the management programmes for tropical rivers, to ensure fish conservation and the sustainability of fisheries.

Our results indicate that protected areas of sustainable use in the Tapajós River, which were designed primarily to protect terrestrial ecosystems, increased the fishing productivity of local fishers. This provides novel insights for the management of large tropical rivers, reinforcing the importance of protected areas co-managed by local people to sustain the socio-ecological systems of small-scale fisheries. In the Brazilian Amazon the failure to achieve environmental and social objectives has been used as an argument to downsize or even change the status of protected areas to allow development projects to proceed (Ferreira et al., 2014). However, our study provides evidence that protected areas are important for social and environmental purposes and should be maintained. On the other hand, the biological parameters of fish assemblages in the floodplain lakes were correlated more with environmental factors than with the existence of protected areas. This lack of effect of protected areas may be partially explained by differences in fishing pressure between the floodplain lakes and the main river channel, by the effect of small-scale management in some lakes, and by the influence of environmental variables on fish assemblages. The environmental variation between lakes must therefore be considered in the establishment of protected areas and conservation programmes in tropical rivers.

\section{Acknowledgements}

We thank the Coordination for the Improvement of Higher Education Personnel (CAPES) and National Council for Scientific and Technological Development (CNPq) for scholarships to RAMS (309014/2013-1), a PhD scholarship to $\mathrm{GH}$, and MSc and $\mathrm{PhD}(1286-15-13)$ scholarships to FWK; CAPES Programa Nacional de Cooperação Acadêmica (Procad)/Ação Novas Fronteiras (NF; 883/ 2010) for funding the research; and Instituto Chico Mendes de Conservação da Biodiversidade (ICMBio) for a 
permit to interview fishers and to conduct fish sampling in the protected areas. We also thank Frank Ribeiro, Cárlison Oliveira and André Canto for fish identification, Ana Bevilacqua and Natália Roos for help with field work, and Leonardo Maltchik, Érica Caramaschi and Sandra Hartz for helpful suggestions regarding the manuscript.

\section{References}

Abraham, R.K. \& Kelkar, N. (2012) Do terrestrial protected areas conserve freshwater fish diversity? Results from the Western Ghats of India. Oryx, 46, 544-553.

Allan, J.D., Abell, R., Hogan, Z., Revenga, C., Taylor, B.W., Welcomme, R.L. \& Winemiller, K. (2005) Overfishing of inland waters. BioScience, 55, 1041-1051.

Almeida, O.T., Lorenzen, K. \& McGrath, D.G. (2009) Fishing agreements in the lower Amazon: for gain and restraint. Fisheries Management and Ecology, 16, 61-67.

ANA (Agência Nacional de Águas) (2012) Santarém-Rio Tapajós: monitoramento hidrológico de 2012. Http://www.ana.gov. br [accessed 11 May 2013].

Andersen, K.H. \& Pedersen, M. (2010) Damped trophic cascades driven by fishing in model marine ecosystems. Proceedings of the Royal Society B, 277, 795-802.

Arrington, D.A., Winemiller, K.O. \& Layman, C.A. (2005) Community assembly at the patch scale in a species rich tropical river. Oecologia, 144, 157-167.

Barthem, R. \& Goulding, M. (1997) The Catfish Connection: Ecology, Migration, and Conservation of Amazon Predators. Columbia University Press, New York, USA.

Bates, D., Maechler, M., Bolker, B. \& Walker, S. (2014) lme4: Linear mixed-effects models using Eigen and $\mathrm{S}_{4}$, R package version 1.1-7. Http://CRAN.R-project.org/package $=$ lme 4 [accessed 1 November 2014].

Bayley, P.B. \& Petrere, JR, M. (1989) Amazon fisheries: assessment methods, current status and management points. In Proceedings of the International Large River Symposium (ed. D.P. Dodge), pp. 385398. Canadian Special Publication of Fisheries and Aquatic Sciences (106), Fisheries and Oceans Canada, Ottawa, Canada.

Begossi, A., Silvano, R.A.M., Amaral, B.D. \& Oyakawa, O.T. (1999) Use of fish and game by inhabitants of an extractive reserve (Upper Juruá, Acre, Brazil). Environment, Development and Sustainability, 1, 73-93.

Benedito-Cecilio, E. \& Araujo-Lima, C.A.R.M. (2002) Variation in the carbon isotope composition of Semaprochilodus insignis, a detritivorous fish associated with oligotrophic and eutrophic Amazonian rivers. Journal of Fish Biology, 60, 1603-1607.

Blanco-Parra, M.P. \& Bejarano-Rodríguez, I. (2006) Alimentación y reproducción de las principales espécies ícticas del río Mesay durante el período de "aguas altas". Revista de Biología Tropical, 54, 853-859.

Burnham, K.P. \& Anderson, D.R. (2002) Model Selection and Multimodel Inference: An Information Theoretic Approach. Springer, New York, USA.

Calcagno, V. (2013) glmulti: Model Selection and Multimodel Inference Made Easy, R package Version 1.o.7. Http://CRAN. R-project.org/package $=$ glmulti [accessed 5 November 2014].

Campbell, S.J., Cinner, J.E., Ardiwijaya, R.L., Pardede, S., Kartawijaya, T., Mukmunin, A. et al. (2012) Avoiding conflicts and protecting coral reefs: customary management benefits marine habitats and fish biomass. Oryx, 46, 486-494.
Castello, L., Arantes, C.C., McGrath, D.G., Stewart, D.J. \& DE SousA, F.S. (2015) Understanding fishing-induced extinctions in the Amazon. Aquatic Conservation, 25, 587-598.

Castello, L., McGrath, D.G. \& Beck, P.S.A. (2011) Resource sustainability in small-scale fisheries in the Lower Amazon floodplains. Fisheries Research, 110, 356-364.

Castello, L., McGrath, D.G., Hess, L.L., Coe, M.T., Lefebvre, P.A., Petry, P. et al. (2013) The vulnerability of Amazon freshwater ecosystems. Conservation Letters, 6, 217-229.

Castello, L., Viana, J.P., Watkins, G., Pinedo-Vasquez, M. \& LuZADIS, V.A. (2009) Lessons from integrating fishers of arapaima in small-scale fisheries management at the Mamirauá Reserve, Amazon. Environmental Management, 43, 197-209.

Claudet, J. (2011) Marine Protected Areas: A Multidisciplinary Approach. Cambridge University Press, Cambridge, UK.

Fernandes, C.C. (1997) Lateral migration of fishes in Amazon floodplains. Ecology of Freshwater Fish, 6, 36-44.

Ferreira, J., Aragão, L.E.O.C., Barlow, J., Barreto, P., Berenguer, E., Bustamante, M. et al. (2014) Brazil's environmental leadership at risk: mining and dams threaten protected areas. Science, 346, 706-707.

Freitas, M.H.M. (2007) Dieta e estrutura trófica da assembleia de peixes bentônicos em um trecho do baixo rio Trombetas (Oriximiná, Pará, Brasil). MSc thesis. Universidade Federal do Amazonas, Manaus, Brazil.

Froese, R. \& Pauly, D. (eds) (2014) FishBase. Http://www.fishbase. org [accessed 2 November 2014].

Galacatos, K., Barriga-Salazar, R. \& Stewart, D.J. (2004) Seasonal and habitat influences on fish communities within the lower Yasuni River basin of the Ecuadorian Amazon. Environmental Biology of Fishes, 71, 33-51.

Garcia, A., Tello, S., Vargas, G. \& Duponchelle, F. (2009) Patterns of commercial fish landings in the Loreto region (Peruvian Amazon) between 1984 and 2006. Fish Physiology and Biochemistry, $35,53-67$.

Gelcich, S., Godoy, N., Prado, L., Castilla, J.C. (2008) Add-on conservation benefits of marine territorial user rights fishery policies in Central Chile. Ecological Applications, 18, 273-281.

Gell, F.R. \& Roberts, C.M. (2003) Benefits beyond boundaries: the fishery effects of marine reserves. Trends in Ecology and Evolution, $18,448-455$.

Godor, D.S. (2008) Diversidade e hábitos alimentares de peixes de afluentes do Rio Teles Pires, drenagem do Rio Tapajós, bacia amazônica. $\mathrm{PhD}$ thesis. São Paulo State University, São Paulo, Brazil.

González, N. \& Vispo, C. (2002) Aspects of the diet and feeding ecologies of fish from nine floodplain lakes of the lower Caura, Venezuelan Guayana. Scientia Guaianae, 12, 329-366.

Gotelli, N.J. \& Colwell, R.K. (2011) Estimating species richness. In Biological Diversity: Frontiers in Measurement and Assessment (eds A.E. Magurran \& B.J. McGill), pp. 39-54. Oxford University Press, New York, USA.

Goulding, M., Barthem, R. \& Ferreira, E. (2003) The Smithsonian Atlas of the Amazon. Smithsonian Books, Washington, DC, USA.

Gupta, N., Kanagavel, A., Dandekar, P., Dahanukar, N., Sivakumar, K., Mathur, V.B. \& Raghavan, R. (2016a) God's fishes: religion, culture and freshwater fish conservation in India. Oryx, 50, 244-249.

Gupta, N., Nautiyal, P., Borgohain, A., Sivakumar, K., Mathur, V.B. \& Chadwick, M.A. (2016b) Catch-and-release angling as a management tool for freshwater fish conservation in India. Oryx, 50, 250-256.

Hallwass, G. (2015) Etnoecologia e pesca: influência de unidades de conservação e aplicação do conhecimento ecológico local de 
pescadores no manejo e conservação dos recursos pesqueiros no baixo Rio Tapajós, Amazônia brasileira. $\mathrm{PhD}$ thesis. Federal University of Rio Grande do Sul, Porto Alegre, Brazil.

Hallwass, G., Lopes, P.F., Juras, A.A. \& Silvano, R.A.M. (2011) Fishing effort and catch composition of urban market and rural villages in Brazilian Amazon. Environmental Management, 47, 188200.

Hallwass, G., Lopes, P.F., Juras, A.A., \& Silvano, R.A.M. (2013a) Behavioral and environmental influences on fishing rewards and the outcomes of alternative management scenarios for large tropical rivers. Journal of Environmental Management, 128, 274-282.

Hallwass, G., Lopes, P.F., Juras, A.A. \& Silvano, R.A.M. (2013b) Fishers' knowledge identifies environmental changes and fish abundance trends in impounded tropical rivers. Ecological Applications, 23, 392-407.

Hallwass, G. \& Silvano, R.A.M. (2015) Patterns of selectiveness in the Amazonian freshwater fisheries: implications for management. Journal of Environmental Planning and Management. Http://dx.doi. org/10.108o/09640568.2015.1081587.

Halpern, B.S. (2003) The impact of marine reserves: do reserves work and does reserve size matter? Ecological Applications, 13, 117-137.

Hawlitschek, O., Yamamoto, K.C. \& Carvalho-Neto, F.G.M.R. (2013) Diet composition of fish assemblage of Lake Tupe, Amazonas, Brazil. Revista Colombiana de Ciencia Animal, 5, 313-326.

Herrán, R.A. (1998) Analisis de contenidos estomacales em peces: revision bibliografica de los objetivos y la metodología. Informes técnicos (Instituto Español de Oceanografía), 63, 1-73.

Hoeinghaus, D.J., Agostinho, A.A., Gomes, L.C., Pelicice, F.M., OKADA, E.K., LAtini, J.D. et al. (2009) Effects of river impoundment on ecosystem services of large tropical rivers: embodied energy and market value of artisanal fisheries. Conservation Biology, 23, 1222-1231.

ibama (Instituto Brasileiro do Meio Ambiente e dos Recursos Naturais Renováveis) (2004) Floresta nacional do Tapajós-Plano de manejo. Ministério do Meio Ambiente, Brasília, Brazil.

iCMBio (Instituto Chico Mendes de Conservação da Biodiversidade) (2008) Plano de manejo da reserva extrativista Tapajós-Arapiuns. Ministério do Meio Ambiente, Santarém, Brazil.

iCMBio (Instituto Chico Mendes de ConservaÇão da Biodiversidade) (2015) Unidades de conservação. Http://www. icmbio.gov.br/portal/unidades-de-conservacao.html [accessed 10 September 2015].

inPe (Instituto Nacional de Pesquisas Espaciais) (2014) Image catalog. Http://www.dgi.inpe.br/CDSR/ [accessed 1 September 2014].

IsaAc, V.J., Da Silva, C.O. \& Ruffino, M.L. (2008) The artisanal fishery fleet of the lower Amazon. Fisheries Management and Ecology, 15, 179-187.

Junk, W.J., Bayley, P.B. \& Sparks, R.E. (1989) The flood pulse concept in river-floodplain systems. Canadian Journal of Fisheries and Aquatic Sciences, 106, 110-127.

LA Usche, B. (2011) Guidelines for Protected Areas Legislation. IUCN, Gland, Switzerland.

Layman, C.A., Winemiller, K.O., Arrington, D.A. \& Jepsen, D.B. (2005) Body size and trophic position in a diverse tropical food web. Ecology, 86, 2530-2535.

Lockwood, M., Worboys, G.L. \& Kothari, A. (2006) Managing Protected Areas: A Global Guide. Routledge, Trowbridge, UK.

Lopes, P.F.M., Silvano, R.A.M. \& Begossi, A. (2011) Extractive and sustainable development reserves in Brazil: resilient alternatives to fisheries? Journal of Environmental Planning and Management, 54, $421-443$
Maccord, P.F.L., Silvano, R.A.M., Ramires, M.S., Clauzet, M. \& Begossi, A. (2007) Dynamics of artisanal fisheries in two Brazilian Amazonian reserves: implications to co-management.

Hydrobiologia, 583, 365-376.

Melo, C.E., Machado, F.A. \& Pinto-Silva, V. (2004) Feeding habits of fish from a stream in the savanna of Central Brazil, Araguaia Basin. Neotropical Ichthyology, 2, 37-44.

Mérona, B. de \& Rankin-De-Mérona, J. (2004) Food resource partitioning in a fish community of the central Amazon floodplain. Neotropical Ichthyology, 2, 75-84.

Mérona, B., Santos, G.M. \& Almeida, R.G. (2001) Short term effects of Tucuruí Dam (Amazonia, Brazil) on the trophic organization of fish communities. Environmental Biology of Fishes, 6o, 375-392.

Miranda, L.E. (2011) Depth as an organizer of fish assemblages in floodplain lakes. Aquatic Sciences, 73, 211-221.

Nel, J.L., Roux, D.J., Maree, G., Kleynhans, C.J., Moolman, J., Reyers, B. et al. (2007) Rivers in peril inside and outside protected areas: a systematic approach to conservation assessment of river ecosystems. Diversity and Distributions, 13, 341-352.

Ounboundisane, S., Ainsley, S. \& Patricio, H. (2013) Evaluation of spillover contribution from Fish Conservation Zones (Freshwater Protected Areas) to village fishing catches in the Nam Kading River, Bolikhamxay Province, Lao PDR. Http://fishbio.com/wp-content/ uploads/Floy-tagging-research-report_Final.pdf [accessed 2 February 2015].

Palumbi, S.R. (2004) Marine reserves and ocean neighborhoods: the spatial scale of marine populations and their management. Annual Review of Environment and Resources, 29, 31-68.

Pauly, D., Christensen, V., Dalsgaard, J., Froese, R. \& Torres, JR, F. (1998) Fishing down marine food webs. Science, 279, 860-863.

Pauly, D., Palomares, M.L., Froese, R., Sa-a, P., Vakily, M., Preikshot, D. \& Wallace, S. (2001) Fishing down Canadian aquatic food webs. Canadian Journal of Fisheries and Aquatic Sciences, 58, 51-62.

PDT (Plan Development Team) (1990) The Potential of Marine Fishery Reserves for Reef Fish Management in the U.S. Southern Atlantic. NOAA Technical Memorandum NMFS-SEFC-261, 40 p. Http://safmc.net/managed-areas/pdf/source-documents/NOAA\% 20Technical\%20MemoNMFSSEFC261.pdf [accessed 5 March 2015].

Petry, P., Bayley, P.B. \& MARKLe, D.F. (2003) Relationships between fish assemblages. macrophytes and environmental gradients in the Amazon River floodplain. Journal of Fish Biology, 63, 547-579.

Pinkas, L., Oliphant, M.S. \& Iverson, I.L.K. (1971) Food habits of albacore, bluefin tuna, and bonito in California waters. California Department of Fish and Game, Fish Bulletin, 152, 1-105.

R Development Core Team (2014) R: A Language and Environment for Statistical Computing. R Foundation for Statistical Computing, Vienna, Austria.

Roche T, M.-J. (1998) Short-term effects of fishing on life history traits of fishes. ICES Journal of Marine Science, 55, 371-391.

Rodriguez, M.A. \& Lewis, JR, W.M. (1997) Structure of fish assemblages along environmental gradients in floodplain lakes of the Orinoco River. Ecological Monographs, 67, 109-128.

Rodríguez-Olarte, D., Taphorn, D.C. \& Lobón-Cerviá, J. (2011) Do protected areas conserve neotropical freshwater fishes? A case study of a biogeographic province in Venezuela. Animal Biodiversity and Conservation, 34, 273-285.

Saint-Paul, U., Zuanon, J., Correa, M.A.V., García, M., Fabré, N.N., BERGER, U. \& JUnK, W.J. (2000) Fish communities in central Amazonian white- and blackwater floodplains. Environmental Biology of Fishes, 57, 235-250.

SÁ-Oliveira, J.C., Angelini, R. \& Isaac-Nahum, V.J. (2014) Diet and niche breadth and overlap in fish communities within the area 
affected by an Amazonian reservoir (Amapá, Brazil). Anais da Academia Brasileira de Ciências, 86, 383-405.

Silva, C.C. (2006) Dieta da comunidade de peixes na área de influência da UHE de Balbina-Rio Uatumã, Amazonas, Brasil. MSc thesis. Universidade Federal do Amazonas, Manaus, Brazil.

Silva, C.C., Ferreira, E.J.G. \& Deus, C.P. (2008a) Dieta de cinco espécies de Hemiodontidae (Teleostei, Characiformes) na área de influência do reservatório de Balbina, rio Uatumã, Amazonas, Brasil. Iheringia, 98, 464-468.

Silva, C.C., Ferreira, E.J.G. \& Deus, C.P. (2008b) Diet of Bryconops alburnoides and B. caudomaculatus (Osteichthyes: Characiformes) in the region affected by Balbina Hydroelectric Dam (Amazon drainage, Brazil). Neotropical Ichthyology, 6, 237-242.

Silvano, R.A.M., Hallwass, G., Lopes, P.F., Ribeiro, A.R., Lima, R.P., HASENACK, H. et al. (2014) Co-management and spatial features contribute to secure fish abundance and fishing yields in tropical floodplain lakes. Ecosystems, 17, 271-285.

Silvano, R.A.M., Ramires, M. \& Zuanon, J. (2009) Effects of fisheries management on fish communities in the floodplain lakes of a Brazilian Amazonian Reserve. Ecology of Freshwater Fish, 18, 156-166.

Silvano, R.A.M., Zuanon, J.A.S., ZahorcsaK, P., Ramos, R.M. \& Begossi, A. (2005) Fish ecology and fisheries in Negro River (Brazilian Amazon). In Annual Meeting of the Association for Tropical Biology and Conservation, p. 71. Frontiers in Tropical Biology and Conservation, Uberlândia, Brazil.

Suski, C.D. \& CoOKE, S.J. (2007) Conservation of aquatic resources through the use of freshwater protected areas: opportunities and challenges. Biodiversity Conservation, 16, 2015-2029.

Tejerina-Garro, F.L., Fortin, R. \& Rodríguez, M.A. (1998) Fish community structure in relation to environmental variation in floodplain lakes of the Araguaia River, Amazon Basin. Environmental Biology of Fishes, 51, 399-410.
Vasconcellos, H.C.G. \& Oliveira, J.C.S. (2011) Alimentação de Potamotrygon motoro (CHONDRICHTHYES,

POTAMOTRYGONIDAE) na planície de inundação da APA do

Rio Curiaú, Macapá-Amapá-Brasil. Biota Amazônia, 1, 66-73.

Veríssimo, A., Rolla, A., Vedoveto, M. \& de Furtada, S.M. (eds) (2011) Áreas protegidas na Amazônia Brasileira: avanços e desafios. Imazon/ISA, São Paulo, Brazil.

Welcomme, R.L. (1999) A review of a model for qualitative evaluation of exploitation levels in multi-species fisheries. Fisheries Management and Ecology, 6, 1-19.

Welcomme, R.L. (2001) Inland Fisheries: Ecology and Management. Fishing News Books, Oxford, UK.

Winemiller, K.O. (2005) Life history strategies, population regulation, and implications for fisheries management. Canadian Journal of Fisheries and Aquatic Sciences, 62, 872-885.

Winemiller, K.O. \& Jepsen, D.B. (1998) Effects of seasonality and fish movement on tropical river food webs. Journal of Fish Biology, $53,267-296$.

Winter, B. (2013) A Very Basic Tutorial for Performing Linear Mixed Effects Analyses. Http://www.bodowinter.com/tutorial/bw_LME_ tutorial.pdf [accessed 19 December 2014].

\section{Biographical sketches}

Friedrich Wolfgang Keppeler has a broad interest in the fields of ecology and evolution, with a particular concern for the sustainable use of natural resources and biological conservation. Gustavo HALLWASS studies artisanal fisheries and their dynamics, use of natural resources, human ecology and fish ecology. Renato Azevedo Matias Silvano's research interests include artisanal fisheries, use of natural resources, ethnoecology and human ecology. 